
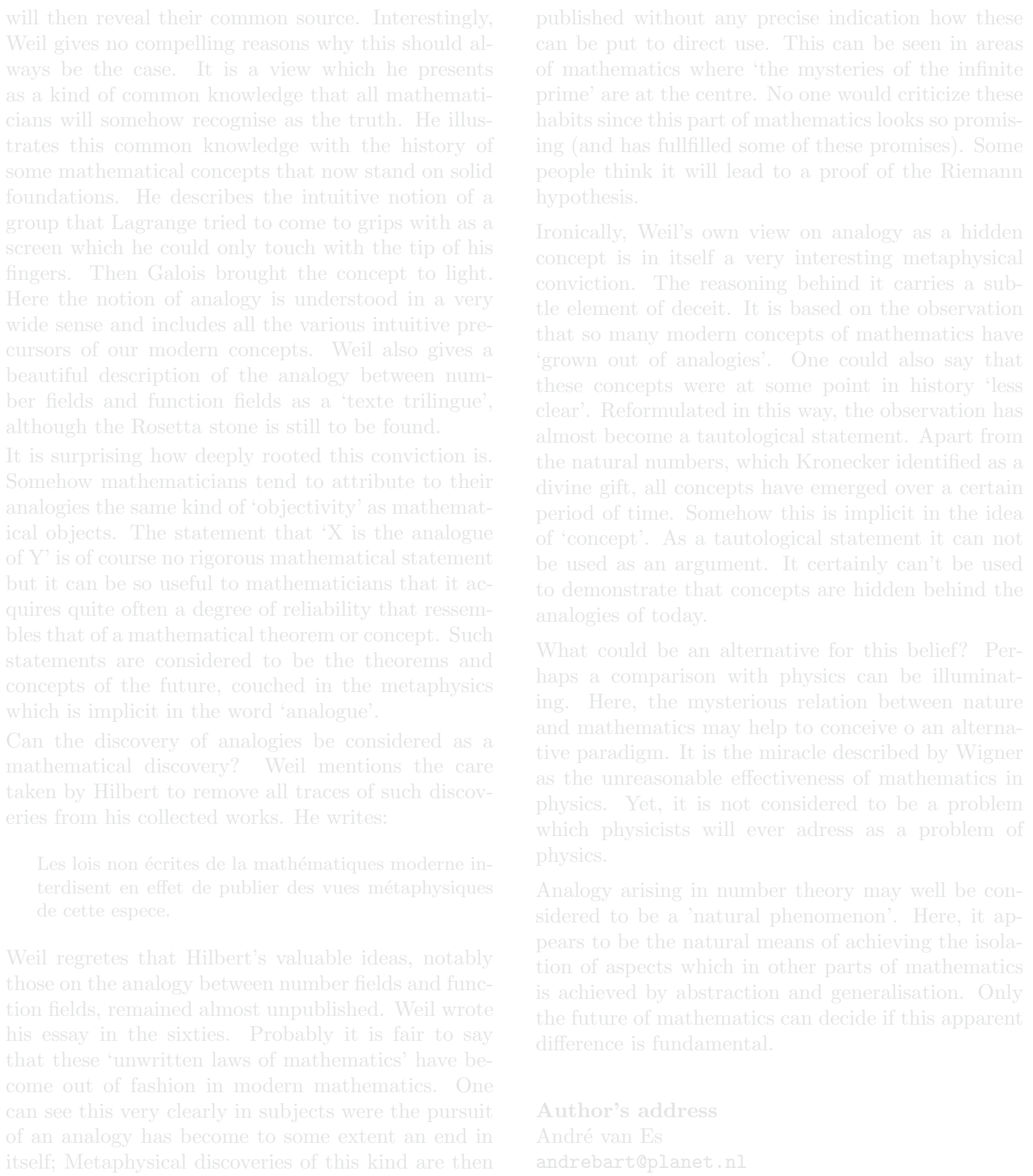

\title{
Aus einer e-mail an www.mathematik.de
}

Liebe MathematikerInnen,

ich bin in der 6. Klasse und wir haben gerade periodische Dezimalbrüche durchgenommen. Wir haben gelernt: $1 / 9=0.111 \ldots, 3 / 9=0.333$ usw.

Was aber ist dann 0.999 ...? Unsere Lehrerin hat gesagt, das wäre 9/9. Das kann aber doch nicht sein.
Das wäre doch 1 und $0.999 \ldots$ ist doch ein Unendlichstel kleiner als 1. Gibt es $0.999 \ldots$ überhaupt? Aber eine Zahl, die ich mir ausdenken kann, muss es doch geben. Wie kommt man an $0.999 \ldots$...?

Ich würde mich über eine Antwort freuen.

Lina 